\title{
Hydrogeological insights at Stromboli volcano (Italy) from geoelectrical, temperature, and $\mathrm{CO}_{2}$ soil degassing investigations
} \author{
$\underset{\text { Sortino }}{\text { A. Finizola, }}{ }^{1,2}$ A. Revil, ${ }^{3}$ E. Rizzo, ${ }^{4}$ S. Piscitelli, ${ }^{4}$ T. Ricci, ${ }^{5}$ J. Morin, ${ }^{2,6}$ B. Angeletti, ${ }^{3}$ L. Mocochain, ${ }^{3}$ and F.
}

[1] Finding the geometry of aquifers in an active volcano is important for evaluating the hazards associated with phreatomagmatic phenomena and incidentally to address the problem of water supply. A combination of electrical resistivity tomography (ERT), self-potential, $\mathrm{CO}_{2}$, and temperature measurements provides insights about the location and pattem of ground water flow at Stromboli volcano. The measurements were conducted along a NE-SW profile across the island from Scari to Ginostra, crossing the summit (Pizzo) area. ERT data (electrode spacing $20 \mathrm{~m}$, depth of penetration of $\sim 200 \mathrm{~m}$ ) shows the shallow architecture through the distribution of the resistivities. The hydrothermal system is characterized by low values of the resistivity $(<50 \Omega \mathrm{m})$ while the surrounding rocks are resistive $(>2000 \Omega \mathrm{m}$ ) except on the North-East flank of the volcano where a cold aquifer is detected at a depth of $\sim 80 \mathrm{~m}$ (resistivity in the range 70-300 $\Omega \mathrm{m}$ ). $\mathrm{CO}_{2}$ and temperature measurements corroborate the delineation of the hydrothermal body in the summit part of the volcano while a negative self-potential anomaly underlines the position of the cold aquifer. Citation: Finizola, A., A. Revil, E. Rizzo, S. Piscitelli, T. Ricci, J. Morin, B. Angeletti, L. Mocochain, and F. Sortino (2006), Hydrogeological insights at Stromboli volcano (Italy) from geoelectrical, temperature, and $\mathrm{CO}_{2}$ soil degassing investigations, Geophys. Res. Lett., 33, L17304.

\section{Introduction}

[2] There are two main reasons to look for the presence of aquifers in volcanic areas. First, water supply in volcanic areas is an increasing problem due to population and tourism increase [e.g., Barberi et al., 1993]. Second, aquifers may interact with magma intrusions to generate powerful and highly dangerous phreato-magmatic explosions. These explosions are difficult to predict. They dissipate high levels of energy in a short period of time [Rittmann, 1931] and can therefore trigger flank collapses with the associated risk of tsunamis in the case of volcanic islands. The

\footnotetext{
${ }^{1}$ Osserv Vesuviano, Istituto Nazionale di Geofisica e Vulcanologia, Sezione di Palermo, Italy.

${ }^{2}$ Now at Laboratoire des Sciences de la Terre de l'Université de la Réunion (LSTUR), Institut de Physique du Globe de Paris, CNRS, UMR 7154, Saint Denis, La Réunion, France.

${ }^{3}$ CNRS-CEREGE, Université Aix-Marseille III, Aix-en-Provence, France.

${ }^{4}$ Istituto di Metodologie per l' Analisi Ambientale, CNR, Potenza, Italy.

${ }^{5}$ Università Roma Tre, Rome, Italy.

${ }^{6}$ Université de la Sorbonne, Paris, France.
}

opposite is also true as flank collapses can cause phreatomagmatic explosions by disrupting water and hydrothermal bodies.

[3] We present here an innovative combination of geoelectrical measurements, temperature, and $\mathrm{CO}_{2}$ data to derive information on the location of ground water flow over the volcanic island of Stromboli. Located in the northern part of the Aeolian arc (Tyrntenian Sea), Stromboli rises to 924 meters above the sea level and its base lies at a depth of $\sim 2 \mathrm{~km}$ on the sea-floor. This volcano is characterized by a persistent rhythmic activity, for more than one millennium [Rosi et al., 2000]. This activity is sometimes disnupted by paroxysmal events [e.g., Barberi et al., 1993]. These paroxysms are related to interactions between the magmatic column and water bodies present in the central part of the edifice [Rittmann, 1931], like during the event of April, 5th 2003. It is not clear however if phreato-magmatic processes were the origin, or a consequence, of these paroxysms. For these reasons, Stromboli appears as an suitable natural laboratory to test the capacity of geoelectrical methods to monitor volcanic activity [Finizola et al., 2002, 2003; Revil et al., 1999, 2004b].

\section{Geological Settings and Background}

[4] Seven major periods separated by one erosional period, four caldera collapses, and one crater and flank collapse, have been recognized at Stromboli volcano. They correspond to Paleostromboli I, II, and III, Scari units, Vancori, Neostromboli, and Recent Stromboli [Hornig-Kjarsgaard et al., 1993]. During these periods, a large variety of magmatypes, typical of subduction-related magma series, have been erupted in a short period of time ( $<100,000$ years). These magma-types range from calc-alkaline and high$\mathrm{K}$-calcalkaline to shoshonitic and strongly shoshonitic magmas [Hornig-Kjarsgaard et al., 1993]. Figure 1 shows the geological map of the volcano. In this complex architecture, we were interested to locate the extension of the hydrothermal system and the presence of cold aquifers.

[5] Finizola et al. [2002] performed a self-potential survey at the scale of the island. The presence of a cold aquifer is detected when there is a negative linear correlation between self-potential data and topography [e.g., Revil et al., 2004a]. Over the whole island, this is the case only above the villages of Piscità and Scari [Finizola et al., 2002].

\section{Ficld Investigations}

[6] In May 2004, we carried out measurements to obtain a set of geophysical data along a profile crossing the whole 


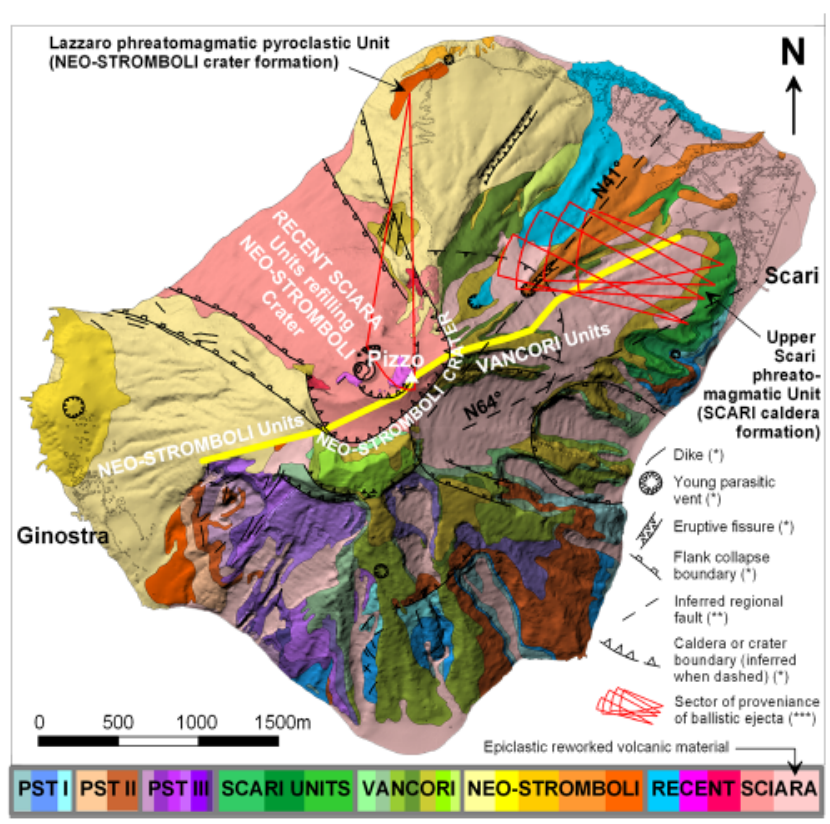

Figure 1. Geological map of Stromboli volcano showing the seven stages constituting the evolution of the edifice (modified from Keller et al. [1993]). The yellow line corresponds to the location of the resistivity profile. PST stands for Paleostromboli (*): from Keller et al. [1993]; (**): from Finizola et al. [2002]; (***): from Nappi et al. [1999].

island, except that the $\mathrm{CO}_{2}$ flux obtained in August, 2005. Because of its sensitivity to the water content and to alteration, electrical resistivity tomography (ERT) is an efficient tool to image active volcanoes. Electrical resistivity measurements were obtained along the profile shown in Figure 1 using a set of 64 brass electrodes (spacing of $20 \mathrm{~m}$ ). This curvilinear profile was $3.78 \mathrm{~km}$ long and required several roll-overs of the electrodes. Contact between the electrodes and the ground was improved when necessary by adding salty water at each electrode location to diminish their contact resistances. We used the Wenner- $\alpha$ array for its good signal-to-noise ratio.

[7] The resistivity data were inverted using RES2DINV [Loke and Barker, 1996]. Topography, obtained using two differential Trimble-GPS stations (accuracy $<1 \mathrm{~m}$ in $z$ ), was included in the inversion of the resistivity data. Accounting for the complex geometry of the volcano, 3-D ERT would be necessary to define the complex structural heterogeneities of the volcanic edifice. However, we show below that 2D-ERT provides an image consistent with the other data (self-potential, temperature, and $\mathrm{CO}_{2}$ ).

[8] Temperature was measured with thermal probes placed at the depth of $30 \pm 2 \mathrm{~cm}$ with a spacing of $20 \mathrm{~m}$ [see Finizola et al., 2003]. The temperature profile provides an independent way to see the extension of the hydrothermal body in the vicinity of the ground surface (Figure 2).

[9] The $\mathrm{CO}_{2}$ soil flux and concentration measurements were obtained with a spacing of $20 \mathrm{~m}$ (uncertainty $<5 \%$ ). The methodology is described by Chiodini et al. [1998] (other volatile emissions at Stromboli volcano are given by
Allard et al. [1994]). $\mathrm{CO}_{2}$ soil concentrations were measured by pumping through a tube ( $2 \mathrm{~mm}$ in diameter) made of copper, which was inserted into the ground at a depth of 0.5 meter. The $\mathrm{CO}_{2}$ concentrations were obtained as a difference of potential after calibration of the infrared photoelectric cell (uncertainty $<5 \%$ ). Carbon dioxide anomalies (i.e., carbon dioxide levels recorded above the atmospheric concentration, $\sim 350 \mathrm{ppm}$ ) mainly have their origin in magma degassing inside the volcanic system. The gas follows the same preferential pathways that the hydrothermal brines providing information about the permeability distribution of the edifice.

[10] Self-Potential (SP) measurements were spaced every $20 \mathrm{~m}$ along the profile. We used a pair of non-polarisable $\mathrm{Cu} / \mathrm{CuSO}_{4}$ electrodes. The difference of electrical potential between the reference electrode (arbitrarily placed at the beginning of the profile) and the moving electrode was measured with a high impedance voltmeter (sensitivity of $0.1 \mathrm{mV}$, internal impedance of $\sim 100 \mathrm{M} \Omega$ ). At each station, a small hole ( $\sim 10 \mathrm{~cm}$ deep) was dug to improve the electrical contact between the electrode and the ground.

\section{Interpretation in Terms of Fluid Flow}

[11] Based on the electrical resistivity values, the ScariGinostra ERT profile can be subdivided in 6 sectors. Three of them are conductive (denoted $\mathrm{C}$ below) with resistivity values $<300 \Omega \mathrm{m}$ and the remaining three are resistive (denoted R) with resistivity $>2 \mathrm{k} \Omega \mathrm{m}$ (Figure 2 ). From the $\mathrm{NE}$ to the $\mathrm{SW}$, we distinguish the sectors $\mathrm{C}_{1}, \mathrm{R}_{1}, \mathrm{C}_{2}, \mathrm{R}_{2}, \mathrm{C}_{3}$, and $\mathrm{R}_{3}$, respectively. In the summit part of the volcano, the conductive body $\mathrm{C}_{3}$ is characterized by the lowest resistivity values, $<50 \Omega \mathrm{m}$, associated with positive temperature, SP and $\mathrm{CO}_{2}$ anomalies. This $\mathrm{C}_{3}$ sector represents the hydrothermal system of Stromboli (Revil et al. [2004b] for a high resolution survey of the crater of Stromboli).

[12] In the southern part of this sector (toward the village of Ginostra), ERT does not evidence any conductive body within the maximum depth investigated. In the northern part of the profile (toward the village of Scari), $\mathrm{C}_{2}$ and $\mathrm{C}_{1}$ have resistivity values that are compatible with a water-saturated high porosity rock. Alternative explanations could exist e.g., the presence of pyroclastites with some clay minerals. However, the negative self-potential signals in this area is typically associated with the presence of a cold aquifer [Finizola et al., 2002]. This implies that a permeable layer is located at the base of the Vancori units.

[13] Due to the elevated temperature and a high content of secondary minerals associated with hydrothermal circulation, the conductivity of the summit hydrothermal system $\left(\mathrm{C}_{3}\right)$ appears to be significantly higher than the cold and less mineralized hydrogeological sectors $\left(\mathrm{C}_{2}\right.$ and $\left.\mathrm{C}_{1}\right)$.

\section{Interpretation in Terms of Structural Settings}

[14] The comparison between our data set (Figure 2) and the geological map of Stromboli island (Figure 1) evidences the following points. (1) The boundary of NeoStromboli crater, built at the end of NeoStromboli period, about 6.000 years ago [Hornig-Kjarsgaard et al., 1993] acts nowadays as a seal for the lateral extension of the hydrothermal system of Stromboli volcano. (2) In the northern 


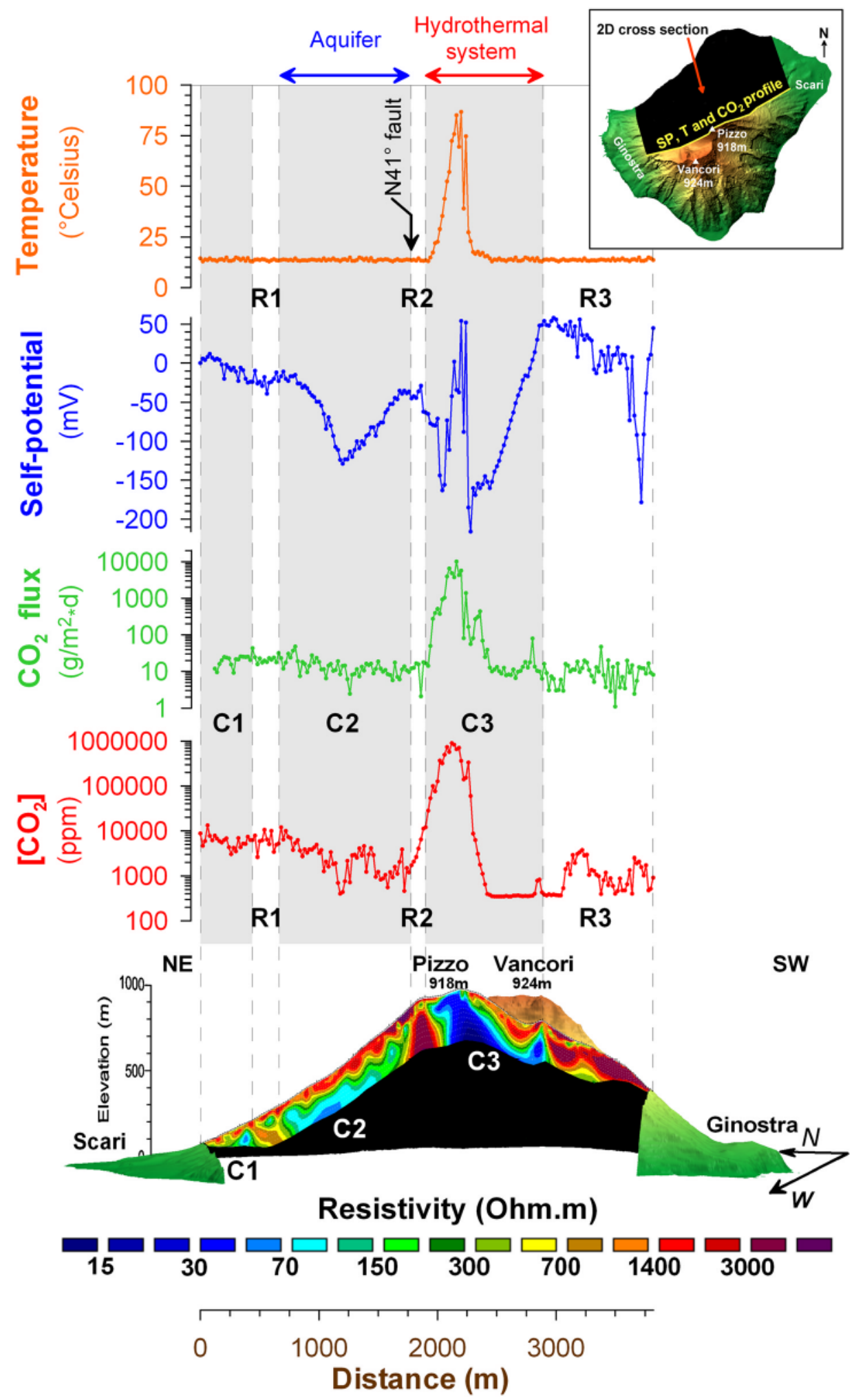

Figure 2. Temperature, self-potential, $\mathrm{CO}_{2}$ measurements made along the electrical resistivity profile crossing the entire Stromboli island, along a NE-SW direction. " $C$ " and " $R$ " stand for the conductive and resistive bodies.

part of the island, the sharp and drastic transition between $\mathrm{R}_{2}$ and $\mathrm{C}_{2}$, corresponding to the beginning of the hydrogeological sector $\mathrm{C}_{2}$, coincides with the regional $\mathrm{N} 41$ faults (Figure 1). This fault is responsible of the general NE-SW alignment of Lipari, Panarea, and Stromboli islands. At Stromboli volcano, a sharp resistivity transition in both sides of this N41 regional fault means that this latter has a very important role in the destructive collapse event that 
shaped the present-day volcanic edifice. A similar importance of the control of faults in the morphological evolution of Stromboli volcano, in particular sector collapse, was already evidenced [Finizola et al., 2002] with the five adjacent sector collapses located in the eastern part of the volcano along the alignment of the $N 64^{\circ}$ fault. The $C_{2}$ sector could be explained by a collapse structure in which the western side was guided by this regional fault. On a geological point of view, the conductive body $\mathrm{C}_{2}$ is overlapped by resistive units corresponding to the compact red lava flow of Vancori Units. This means that this collapse event occurred before the emission of Vancori Units. Considering that the end of the previous period (Scari) was closed by Upper Scari phreatomagmatic unit, and that the sector of origin of the corresponding ballistic ejecta is located near the collapse structure zone evidenced in $\mathrm{C}_{2}$ area from the resistivity tomography profile, we can hypothesize that this drastic vertical resistivity transition between $R_{2}$ and $C_{2}$ is linked to refilled volcanic material inside $\mathrm{C}_{2}$. Such a destructive event in the north-eastern part of the volcano could be related to the collapse crater responsible for the Scari units [Nappi et al., 1999], one of the seven key-periods that produced the structure of Stromboli volcano.

[15] About the conductive bodies $\mathrm{C}_{2}$ and $\mathrm{C}_{3}$, we note that the NeoStromboli crater and the Scari units are associated, in the lower part of the island, with hydromagmatic deposits with a thickness of several tens of meters. These hydromagmatic units are the Lazzaro and Upper Scari units, respectively, shown in Figure 1 [Hornig-Kjarsgaard et al., 1993; Nappi et al., 1999]. Therefore, we assume that $C_{3}$ and $\mathrm{C}_{2}$ result from the collapse of two craters filled with materials more permeable and porous than the surrounding volcanic products. Assuming that these hydromagmatic deposits are characterized by a high porosity, such collapse craters filled by the corresponding eruptive products could explain why old collapse crater boundaries can be nowadays seen by a vertical and abrupt transition in the electrical resistivity of these materials.

\section{Concluding Statements}

[16] An innovative combination of geoelectrical measurements (electrical resistivity and self-potential), temperature, and $\mathrm{CO}_{2}$ measurements reveals the pattern of ground water flow at Stromboli volcano. They show the extension of the hydrothermal system and the presence of a cold aquifer located in the northern part of the island, just above the village of Scari. Because the present data were only obtained along a cross-section, the present work should be only considered as a preliminary step that needs to be extended to get the full-3D architecture of Stromboli. Future works will concern the use of this information to model numerically the hydrothermal system of Stromboli (including the streaming potential signature associated with ground water flow and the $\mathrm{CO}_{2}$ soil degassing) and to model the potential electro-magnetic signature of fracturing [Revil et al., 2003].

[17] Acknowledgments. The INSU-CNRS, the CNR, and the Istituto Nazionale di Geofisica e Vulcanologia (INGV) are thanked for financial support. We also thank the Italian civil protection and A. Zollo, P. Allard, and J.-F. Lénat for the reviews.

\section{References}

Allard, P., J. Carbonnelle, N. Metrich, H. Loyer, and P. Zettwoog (1994), Sulphur output and magma degassing budget of Stromboli volcano, Nature, 368(6469), 326-330.

Barberi, F., M. Rosi, and A. Sodi (1993), Volcanic hazard assessment at Stromboli based on review of historical data, Acta Vulcanol., 3, 173-187. Chiodini, G., R. Cioni, M. Guidi, L. Marini, and B. Raco (1998), Soil CO flux measurements in volcanic and geothermal areas, Appl. Geochem., $13,543-552$.

Finizola, A., S. Sortino, J.-F. Lénat, and M. Valenza (2002), Fluid circulation at Stromboli volcano (Aeolian Islands, Italy) from self-potential and $\mathrm{CO}_{2}$ surveys, J. Volcanol. Geotherm. Res., 116, 1-18.

Finizola, A., S. Sortino, J.-F. Lénat, M. Aubert, M. Ripepe, and M. Valenza (2003), The summit hydrothermal system of Stromboli: New insights from self-potential, temperature, $\mathrm{CO}_{2}$ and fumarolic fluid measurements-Structural and monitoring implications, Bull. Volcanol., 65, 486-504, doi:10.1007/s00445-003-0276-z.

Hornig-Kjarsgaard, I., J. Keller, U. Koberski, E. Stadlbauer, L. Francalanci, and R. Lenhart (1993), Geology, stratigraphy and volcanological evolution of the island of Stromboli, Aeolian arc, Italy, Acta Vulcanol., 3, $21-$ 68.

Keller, J., I. Hornig-Kjarsgaard, U. Koberski, E. Stadlbauer, and R. Lenhart (1993), Geological map of the island of Stromboli, Acta Vulcanol., 3, 3 .

Loke, M. H., and R. D. Barker (1996), Rapid least-squares inversion of apparent resistivity pseudosections by a quasi-Newton method, Geophys. Prospect., 44, $131-152$.

Nappi, G., B. Capaccioni, F. Biagiotti, and O. Vaselli (1999), Upper pyroclastic sequence of the Scari formation: A paroxistic eruption from Stromboli volcano (Aeolian Island, Italy), Acta Vulcanol., 11, 259-264.

Revil, A., V. Naudet, and J. D. Meunier (2004a), The hydroelectric problem of porous rocks: Inversion of the water table from self-potential data, Geophys. J. Int., 159, 435-444.

Revil, A., A. Finizola, F. Sortino, and M. Ripepe (2004b), Geophysical investigations at Stromboli volcano, Italy. Implications for ground water flow, Geophys. J. Int., 157, 426-440.

Revil, A., G. Saracco, and P. Labazuy (2003), The volcano-electric effect, J. Geophys. Res., 108(B5), 2251, doi:10.1029/2002JB001835.

Revil, A., H. Schwaeger, L. M. Cathles, and P. Manhardt (1999), Streaming potential in porous media. 2. Theory and application to geothermal systems, J. Geophys. Res., 104(B9), 20,033-20,048.

Rittmann, A. (1931), Der Ausbruch des Stromboli am 11 September 1930, Zeits. Vulkanol., 14, 47-77.

Rosi, M., A. Bertagnini, and P. Landi (2000), Onset of the persistent activity at Stromboli volcano (Italy), Bull. Volcanol., 62, 294-300.

B. Angeletti, L. Mocochain, and A. Revil, CNRS-CEREGE, Université Aix-Marseille III, BP 80, F-13545 Aix-en-Provence, France. (angeletti@ cerege.fr; mocochain@cerege.fr; revil@cerege.fr)

A. Finizola and J. Morin, Laboratoire des Sciences de la Terre de l'Université de la Réunion (LSTUR), Institut de Physique du Globe de Paris, CNRS, UMR 7154, 15, rue René Cassin, Saint Denis, F-97715 La Réunion, France (anthony.finizola@univ-reunion.fr; julieapi@yahoo.fr)

S. Piscitelli and E. Rizzo, IMAA-CNR, C. da Fontanelle, Marsico Nuovo (PZ) I-85052, Italy. (piscitelli@imaa.cnr.it; rizzo@imaa.cnr.it)

T. Ricci, Università Roma Tre, Largo S. Leonardo, Murialdo, 1, I-000146 Rome, Italy. (t.ricci@uniroma3.it)

F. Sortino Osserv Vesuviano, Istituto Nazionale di Geofisica e Vulcanologia, Sezione di Palermo, Via Ugo la Malfa 153, 90126, Palermo, Italy. (sortino@pa.ingv.it) 